\title{
COLLAPSE SIMULATION OF AMMU HAWU TRADITIONAL TIMBER HOUSE IN NUSA TENGGARA TIMUR, INDONESIA
}

\author{
Cindy Novaria Nada Karina ${ }^{1}$, Ali Awaludin ${ }^{2 *}$, Bambang Suhendro ${ }^{2}$, Pang-jo Chun ${ }^{1}$ \\ ${ }^{1}$ Department of Civil and Environmental Engineering, Faculty of Engineering, Ehime University, Ehime, \\ 3 Bunkyo-cho, Matsuyama, 790-8577, Japan \\ ${ }^{2}$ Department of Civil and Environmental Engineering, Faculty of Engineering, Universitas Gadjah \\ Mada, Jl.Grafika no. 2, UGM Campus, Sleman, Yogyakarta 55281, Indonesia
}

(Received: December 2016 / Revised: March 2017 / Accepted: January 2018)

\begin{abstract}
This study aims to analyze the collapse mechanism of an Ammu Hawutraditional Indonesian house, which has palm wood (Borassus flabellifer) as its main material, by using Wallstat program and extended distinct element method. Wallstat is a collapse analysis program used to determine a building's damage status and likelihood of collapseduring an earthquake. A total of 10 models were generated for numerical simulation. Among them, 1 represented the original structure, 4 were bracing reinforced models, and 5 were shear-wall reinforced models. These models were observed under the conditions of the ElCentro (1940) and Kobe (1995) earthquakes. Results showed that the models reinforced with diagonal bracings used at the first story of the Ammu Hawu house were significantly more effective in collapse prevention than the shear wall reinforcement at the second story.
\end{abstract}

Keywords: Ammu Hawu traditional house; Bracings; Extended distinct element method; Shear walls; Wallstat program

\section{INTRODUCTION}

Kinasih et al. (2014) found that 2,081 earthquakes occurred in Indonesia's Lesser Sunda Islands (LSI) or Nusa Tenggara region at coordinates $9^{\circ} \mathrm{S}$ and $120^{\circ} \mathrm{E}$ during the 1900 to 2014 period. Among these earthquakes, 1,709 had a 4-4.9 magnitude, 336 had a 5-5.9 magnitude, and 36 had a 6-8 magnitude. An earthquake visualization of the LSI region is presented in Figure 1.

In general, factors that influence the failure of traditional Indonesian houses due to earthquakes include the following: proximity to the epicenter, local geological formation, high population density, and imperfect construction (Idham, 2010). Traditional timber houses were not developed with structural engineering considerations, but they can withstand earthquakes without damage to their structural components; one example was the OmoHadatraditional house in North Sumatra province, which survived the 7.7-magnitude Nias earthquake (USGS, 2009). These facts show that traditional houses that use timber materials as their main structural components are able to satisfy earthquake-resistant requirements (Awaludin, 2010 \& Awaludin, 2012).

Although many timber structures have survived earthquakes, some of them have collapsed probably due to the failure of connections. As lateral movement effects during earthquakes are resisted by the stiffness of connections, the structure would collapse if these connections are not

*Corresponding author's email:ali.awaludin@ugm.ac.id, Tel. +62-274-545675, Fax: +62-274-545676

Permalink/DOI: https://dx.doi.org/10.14716/ijtech.v9i3.463 
strong enough (Triyadi \& Harapan, 2009). Moreover, earthquakes areunpredictable and unpreventable natural phenomena.

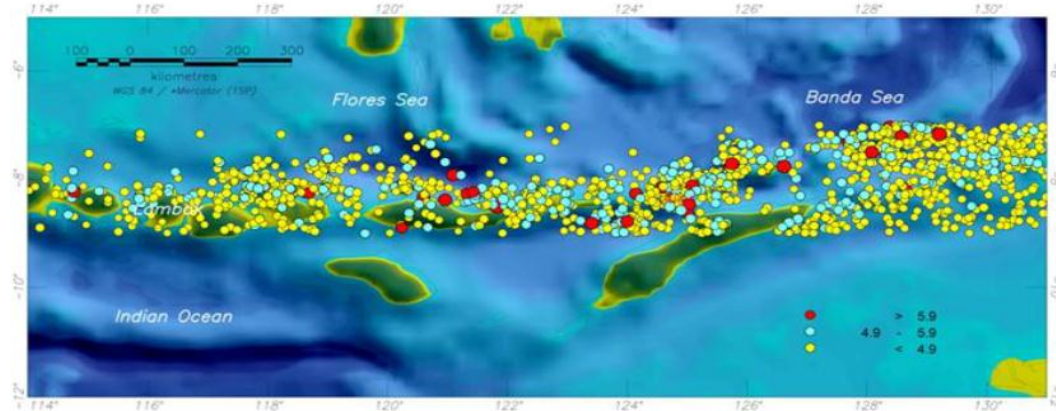

Figure 1 Earthquake visualization of the LSI region from 1900 to 2014 . Yellow dots indicate $4 \leq m_{3}<5$, cyan dots represent $5 \leq m_{2}<6$, and red dots indicate $m_{1} \geq 6$ (Kinasih et al., 2014).

Therefore, unless scientific observation is performed, existing traditional structures may suffer large lateral displacements in the future.

In this study, an Ammu Hawu traditional house in Nusa Tenggara Timur (NTT) province, Indonesia, was chosen as the research object. This house was built with timber as its main material. To maintain the cultural heritage of Indonesian traditional houses and observe the structural behavior of a specific building, the current situation of the Ammu Hawu house was analyzed in the context of the El Centro earthquake in 1940 and the Kobe earthquake in 1995. This study also examined bracings and shear wall reinforcement to determine how the reinforcement systems attract the lateral movement from the two earthquakes. Thus, the current structural behavior of the Ammu Hawu house can be assessed scientifically and used as a reference in strengthening old heritage buildings against future earthquakes.

\section{WALLSTAT MODELS}

Three-dimensional AmmuHawu house models were created and analyzed using the Wallstatprogram based on extended distinct element method (EDEM), which is suitable for large deformation analysis because it is a non-continuum analytical method (Nakagawa \& Ohta, 2003a, Nakagawa \& Ohta, 2003b). The Wallstat program is designed for timber structures according to general frame wall principles. This program requires input values, such as structural component settings (e.g., frame, brace, joint, springs, shear wall, and material properties), and structural weight and loadings, which are inputted manually by the user (Nakagawa et al., 2010). A total of 10 models numbered 0 to 9 were generated and analyzed using external forces of the two aforementioned earthquakes. Model 0 represents the original structure without reinforcement. Models 1 to 5 have various vertical shear-wall configurations added (Table 1). Although the AmmuHawu house traditionally had no walls, vertical shear walls were installed at the second story because they could also be useful as weather protectionfor the dwellers. For models 6 to 9 (Table 1), bracings were added by considering the symmetrical position and nearest location to the center of the structure. The number of braces were gradually increased to improve the stiffness of the first-story structure.

\section{RESEARCH METHOD}

At the first stage, previous related works were reviewed to understand the general structural behavior of traditional timber houses. The literature review was followed by identifying the Ammu Hawu house as the research object in terms of its geometry, history of collapse behavior under earthquakes, and overall structural components. From this step, the position of the 
vertical shear wall and additional timber shear walls can be determined by using Cashew program, version 1.0. Then, 3D models of the house were generated using Wallstat program, version 1.09. All elements, including frames, walls, and weight of the overall structure, were simulated in the Wallstat program. After the 3D models were developed, partial experimental

Table 1 Vertical shear wall and bracing configurations

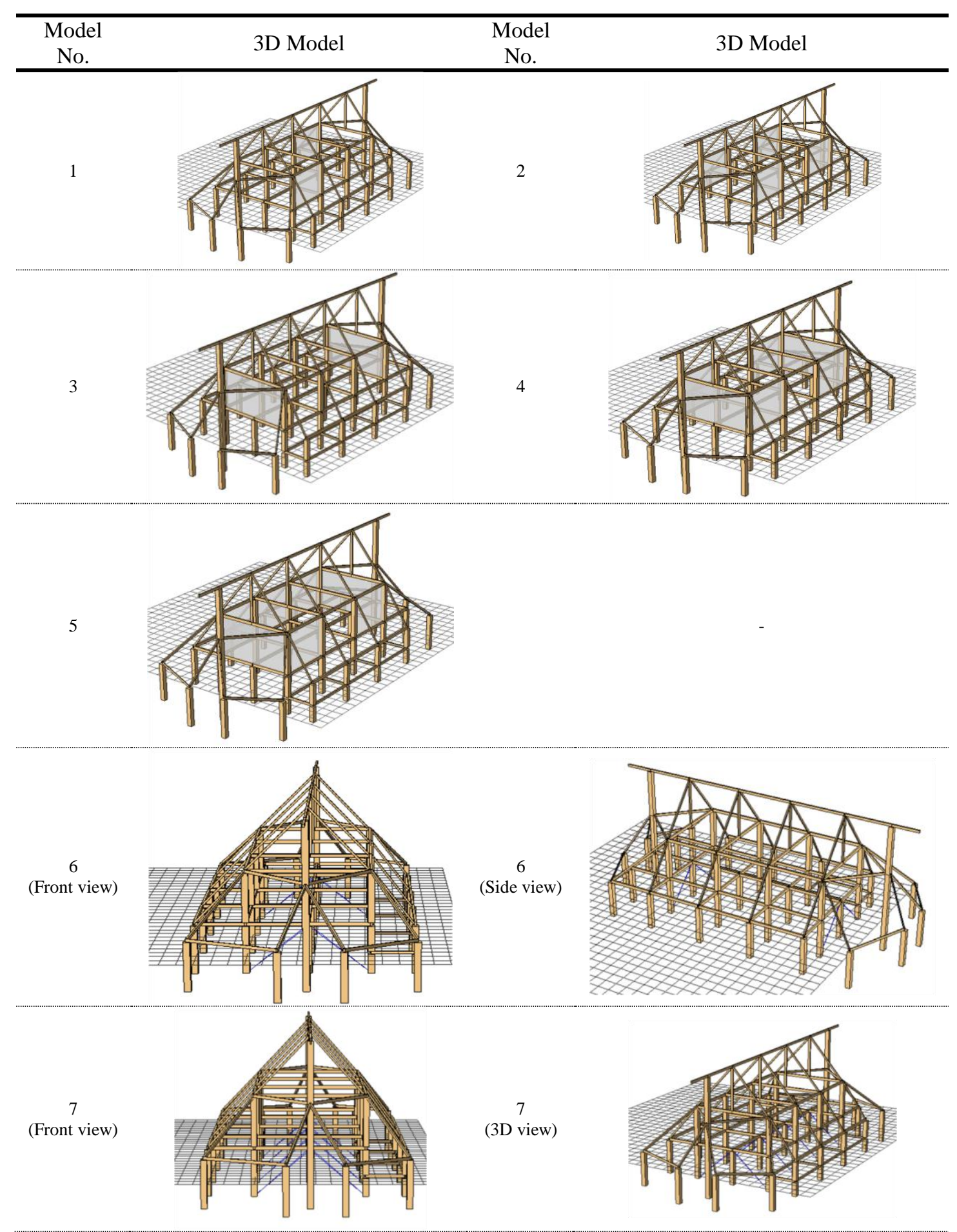




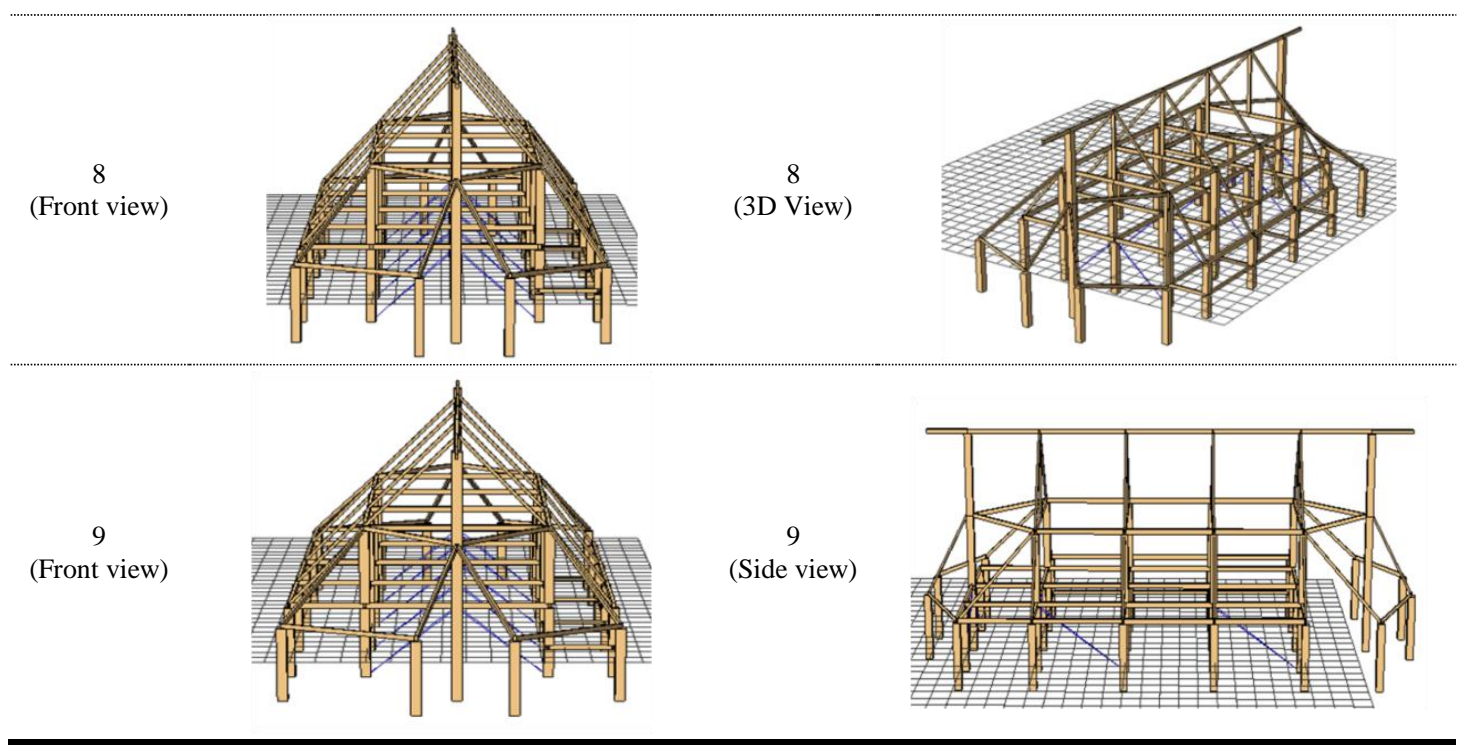

data and Cashew output results were inputted to the models as material properties. The collapse mechanism of the house was then analyzed using the Wallstat program and the output of the analysis, including inertial forces of each member, was further examined and compared to its capacity as defined by the Indonesian National Standard (SNI, 2000).

\subsection{Identification Data of Ammu Hawu Traditional House Structure}

Field survey conducted by the authors and research team PTPT of Denpasar found an existing Ammu Hawu house in Kampung Namata, as shown in Figure 2.

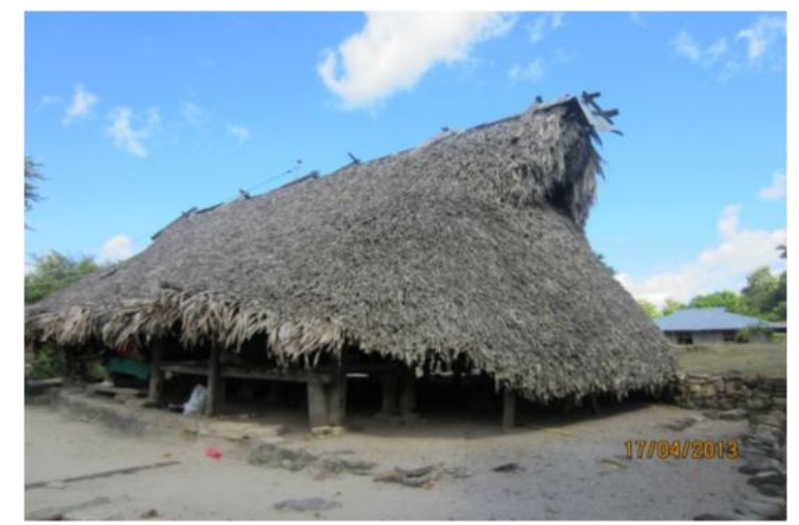

Figure 2 Ammu Hawu traditional house (Suwantara \& Rusli, 2013)

The data structure from the survey is presented in Figure 3. Ammu Hawu houses use palm wood (Borassus flabellifer) as their main structural material. This variety of wood is characterized by tensile strength parallel-to-grain $65.90 \mathrm{MPa}$, tensile strength perpendicular-tograin $19.58 \mathrm{MPa}$, compressive strength parallel-to-grain $50.66 \mathrm{MPa}$, compressive strength perpendicular-to-grain 11.54 MPa, shear strength 4.99 $\mathrm{MPa}$, modulus of rupture $115.78 \mathrm{MPa}$, moisture content $10.5 \%-15.12 \%$, and density $0.82 \mathrm{~kg} / \mathrm{cm}^{3}$.

The cross-section dimensions (diameter) of the house are as follows: floor beam, $60 \mathrm{~mm} \times 120 \mathrm{~mm}$; terrace and residence place beams, $50 \mathrm{~mm} \times 150 \mathrm{~mm}$ and $60 \mathrm{~mm} \times 120 \mathrm{~mm}$, respectively; easel and gable beams, $50 \mathrm{~m} \times 120 \mathrm{~mm}$ and $60 \mathrm{~mm} \times 120 \mathrm{~mm}$, respectively; main and secondary columns, $200 \mathrm{~mm} \times 200 \mathrm{~mm}$ and $150 \mathrm{~mm} \times 150 \mathrm{~mm}$, respectively; and rafter, $50 \mathrm{~mm}$. Joints are assumed to be spring type.Connection types 1 and 2 (Figure 4) were used, where the breaking point of spring load and the breaking point of spring displacement were determined by 
approximating load-displacement curves of the experimental results under monotonic load, as shown in Figure 5 (Awaludin \& Pribadi, 2012). The representative data of the loaddisplacement curves are reported in Table 2.

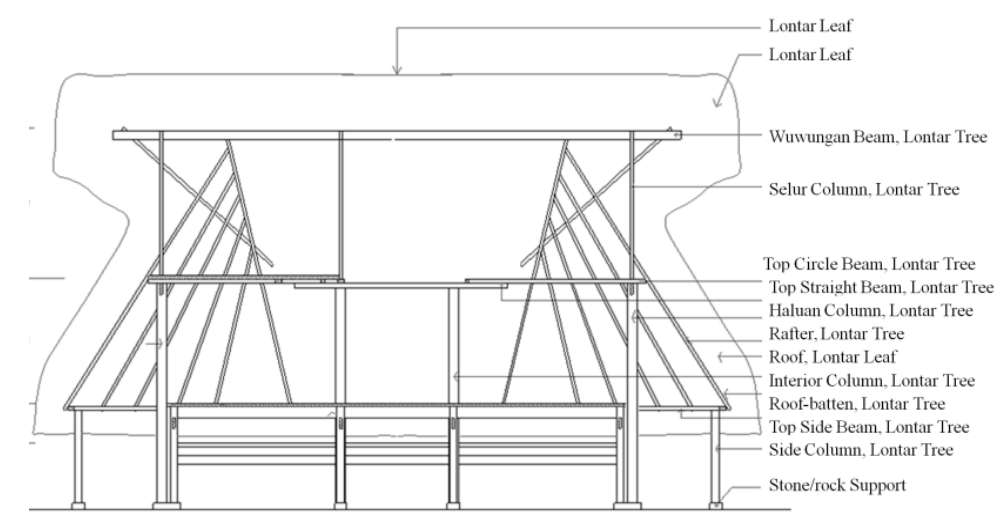

(a)

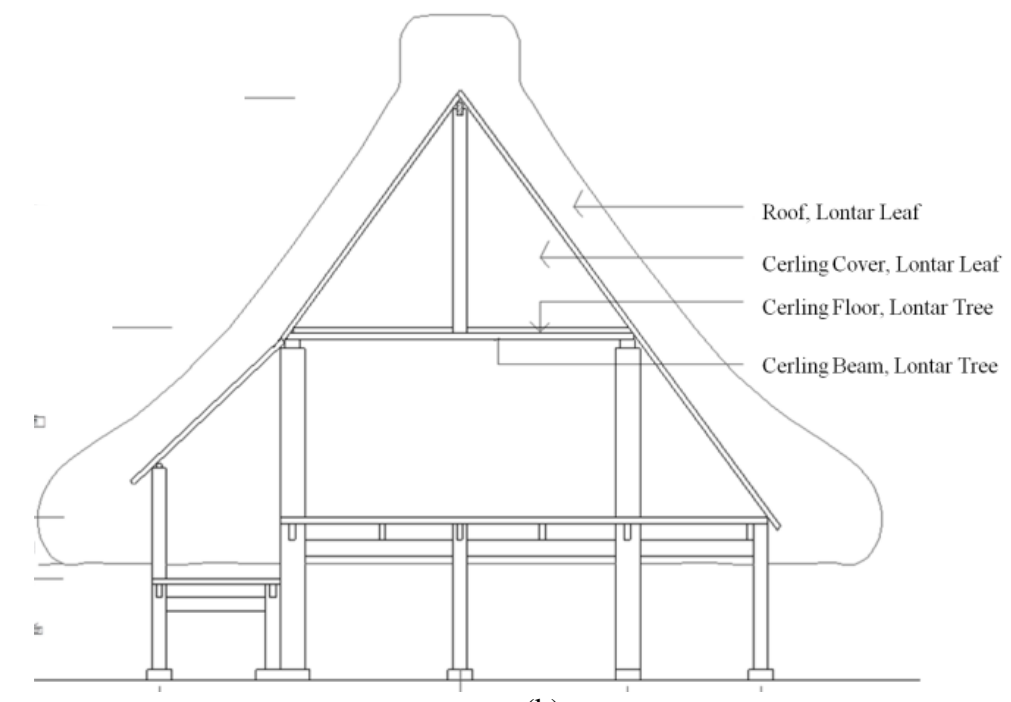

(b)

Figure 3 (a) Section A-A (front view); and (b) Section B-B (side view) (Suwantara \& Rusli, 2013)

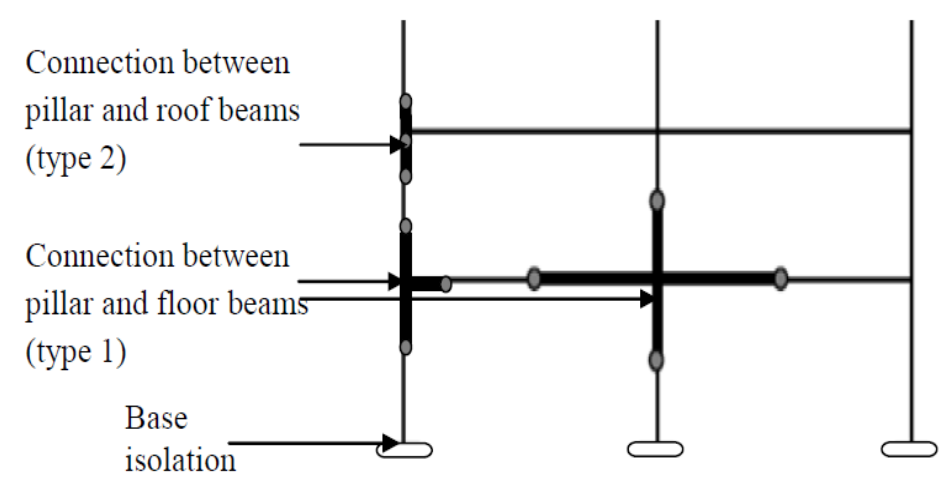

Figure 4 Illustration of typology of connection

In Wallstat, the bracing and shear wall were also assumed to be spring type. The spring parameters of the braces were determined by scaling up or down the sample model, while the shear-wall spring parameters were obtained from the load-displacement curves of cyclic test 
results of the timber panel using Cashew, version 1.0. The representative data of the loaddisplacement curves are shown in Table 3 for the bracing and in Table 4 for the shear wall.
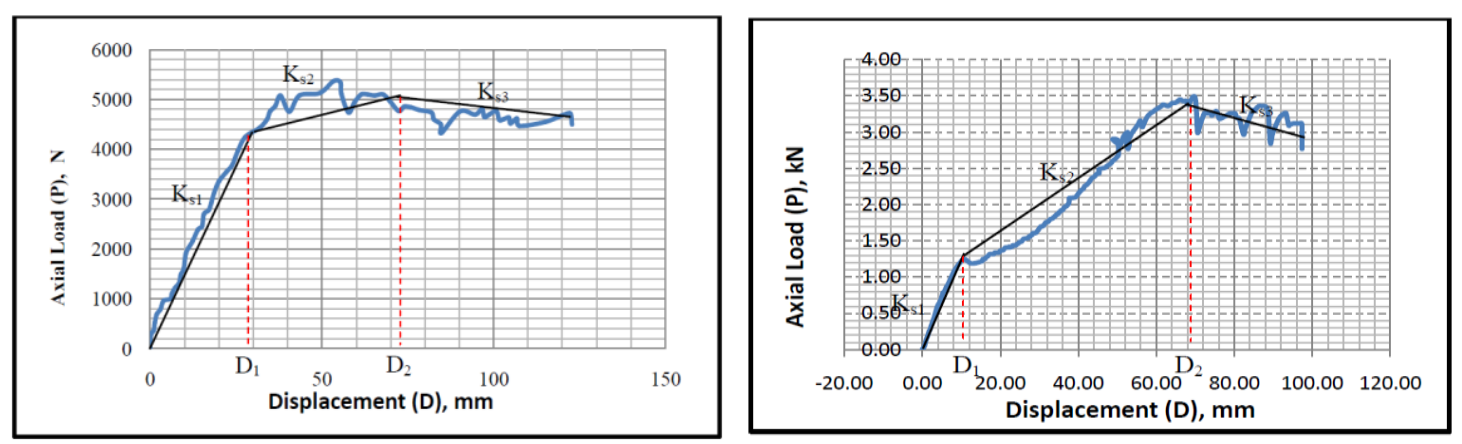

Figure 5 Monotonic experimental results of connection types 1 (left) and 2 (right) (Awaludin\&Pribadi, 2012)

Table 2 Representative data of load-displacement curves of connection types 1 and 2

\begin{tabular}{lcc}
\hline Parameter & Connection Type 1 & Connection Type 2 \\
\hline $\mathrm{K}_{\mathrm{S} 1}(\mathrm{kN} / \mathrm{m})$ & 153.485 & 128.35 \\
$\mathrm{~K}_{\mathrm{S} 1}(\mathrm{kN} / \mathrm{m})$ & 22.057 & 40.83 \\
$\mathrm{~K}_{\mathrm{S} 1}(\mathrm{kN} / \mathrm{m})$ & -6.317 & -18.53 \\
$\mathrm{D}_{1}(\mathrm{~mm})$ & 27.69 & 8.96 \\
$\mathrm{D}_{2}(\mathrm{~mm})$ & 65.32 & 65.29 \\
\hline
\end{tabular}

Table 3 Bracing spring parameters in Wallstat (Building Research Institute, 2010)

\begin{tabular}{cccccccc}
\hline $\mathrm{P}_{1}(\mathrm{kN})$ & $\mathrm{P}_{2}(\mathrm{kN})$ & $\mathrm{P}_{3}(\mathrm{kN})$ & $\mathrm{P}_{4}(\mathrm{kN})$ & $\mathrm{D}_{1}(\mathrm{~m})$ & $\mathrm{D}_{2}(\mathrm{~m})$ & $\mathrm{D}_{3}(\mathrm{~m})$ & $\mathrm{D}_{4}(\mathrm{~m})$ \\
\hline 0.832 & 4.161 & 4.660 & 0 & 0.002 & 0.025 & 0.083 & 0.416 \\
\hline
\end{tabular}

Table 4 Cyclic test results using Cashew, version 1.0 (Awaludin\&Pribadi, 2012)

\begin{tabular}{cccccccc}
\hline $\mathrm{P}_{1}(\mathrm{kN})$ & $\mathrm{P}_{2}(\mathrm{kN})$ & $\mathrm{P}_{3}(\mathrm{kN})$ & $\mathrm{P}_{4}(\mathrm{kN})$ & $\mathrm{D}_{1}(\mathrm{~m})$ & $\mathrm{D}_{2}(\mathrm{~m})$ & $\mathrm{D}_{3}(\mathrm{~m})$ & $\mathrm{D}_{4}(\mathrm{~m})$ \\
\hline 2.270 & 9.998 & 10.309 & 0.906 & 0.015 & 0.045 & 0.051 & 0.051 \\
\hline
\end{tabular}

The column base or pillars of the Ammu Hawu house are not directly in contact with the ground but instead rest on stone. This condition could potentially lead to friction force. Thus, a friction test was conducted by applying axial loads of 1,2, and 3 tons, with lateral load applied to the position nearest to the stone foundation. The friction coefficient values are shown in Table 5. The lateral load-displacement curves of the friction test for the 2-ton axial load is presented in Figure 6. The representative data in Figure 6 are shown in Table 6.

Table 5 Average value of friction coefficient at 1,2, and 3 ton loading

(Suwantara \& Rusli, 2013)

\begin{tabular}{|c|c|c|c|c|}
\hline \multirow{2}{*}{ Specimen } & \multicolumn{3}{|c|}{$\begin{array}{l}\text { Friction coefficient }(m) \text { in } \\
\text { Axial load }\end{array}$} & \multirow[t]{2}{*}{ Average } \\
\hline & 1 ton & 2 ton & 3 ton & \\
\hline Specimen 1 & 0.38 & 0.36 & 0.31 & 0.35 \\
\hline Specimen 2 & 0.18 & 0.59 & 0.52 & 0.43 \\
\hline Specimen 3 & 0.28 & 0.27 & 0.24 & 0.26 \\
\hline \multicolumn{4}{|c|}{ Average of all specimens } & 0.35 \\
\hline
\end{tabular}



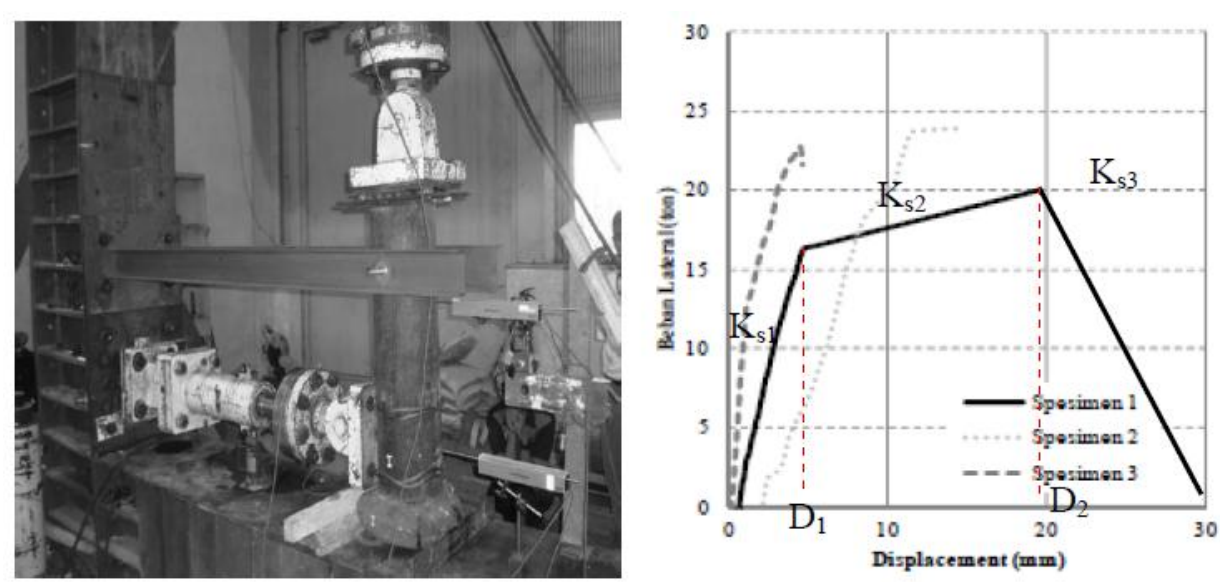

Figure 6 Load-displacement curve of friction test in 2-ton axial load (Suwantara \& Rusli, 2013)

Table 6 Representative data of load-displacement curves of friction test with 2-ton axial load(Suwantara \& Rusli, 2013)

\begin{tabular}{cc}
\hline Parameter & Friction test in 2-ton axial load \\
\hline $\mathrm{K}_{\mathrm{S} 1}(\mathrm{kN} / \mathrm{m})$ & 32000 \\
$\mathrm{~K}_{\mathrm{S} 1}(\mathrm{kN} / \mathrm{m})$ & 2666.67 \\
\hline $\mathrm{K}_{\mathrm{S} 1}(\mathrm{kN} / \mathrm{m})$ & -20000 \\
\hline $\mathrm{D}_{1}(\mathrm{~mm})$ & 5 \\
\hline $\mathrm{D}_{2}(\mathrm{~mm})$ & 20 \\
\hline
\end{tabular}

\subsection{Combination of Bending and Axial Loading Structural Component}

According to SNI (2000) Procedures for Wood Structure Planning for Building Buildings(Tata Cara Perencanaan Struktur Kayu Untuk Bangunan Gedung) beta version, cross-section resistance of structural components relative to bending and axial tension load must be determined on both tension and compression sides when a review of lateral stability is not necessary and when the axial tension force is not dominant enough on the compression side, such that lateral torsion buckling becomes decisive and the following equations must be satisfied:

1. Tension side ${ }^{*}$

$$
\frac{T_{u}}{\lambda \phi_{b} T^{\prime}}+\frac{M_{u x}}{\lambda \phi_{b} M_{s}^{\prime}}+\frac{M_{u y}}{\lambda \phi_{b} M_{y}^{\prime}} \leq 1.0
$$

*Note: Lateral stability interaction is assumed to have occurred.

2. Compression side ${ }^{* *}$

$$
\frac{\left(M_{u x}-\frac{d}{6} T_{u}\right)}{\lambda \phi_{b} M^{\prime}{ }_{x}}+\frac{M_{u y}}{\lambda \phi_{b} M_{y}^{\prime}\left(1-\frac{M_{u x}}{\phi_{b} M_{e}}\right)^{2}} \leq 1.0 .
$$

**Note:Interaction with axial tension force increases the cross-section resistance to lateral torsion buckling.

In Equations 1 and $2, T_{u}$ is the factored tension force $(\mathrm{N}), M_{u x}, M_{u y}$ is the factored bending moment toward strong and weak axis directions $(\mathrm{N}-\mathrm{mm}), T^{\prime}$ is the adjusted tensile resistance 
$(\mathrm{N}), \lambda$ is the load duration factor, $\phi_{b}$ is thebending resistance reduction factor, $M_{x}^{\prime}, M_{y}^{\prime}$ is the adjusted bending resistance toward strong and weak axis, considering the existing lateral bracing $(\mathrm{N}-\mathrm{mm}), M_{e}$ is the elastic lateral buckling moment $(\mathrm{N}-\mathrm{mm}), M^{\prime}{ }_{s}=M^{\prime}{ }_{x}$ is $\quad$ calculated using beam stability factor $\left(\mathrm{C}_{\mathrm{L}}\right)$, which is equal to 1.0 and considering volume factor, $\mathrm{C}_{\mathrm{V}}, \mathrm{N}$ $\mathrm{mm}$.

For non-rectangular structural components, $d / 6$ factor in the first term, where $d$ is height of the component structure itself, must be replaced by $S_{x} / A$, which indicates a comparison between cross-section modulus at strong axis direction $\left(S_{\mathrm{x}}\right)$ and gross cross-sectional area $(A)$.

3. Interactions at compression side without axial tension force

If the axial force does not work simultaneously with the bending moment, then Equation2 has to be fulfilled by assuming that the axial force, $T_{u}$, is equal to zero.

\section{RESULTS AND DISCUSSIONS}

Analysis and simulation models of the Ammu Hawu house were tested on the basis of the El Centro earthquake at point $\mathrm{A}(\mathrm{x}, \mathrm{y}, \mathrm{z}=3.8 \mathrm{~m}, 3.48 \mathrm{~m}, 0 \mathrm{~m}$, respectively) at the upper end of column 81 and at point B at the edge of beam 301, as shown in Figure7.

Based on the output data from Wallstat, model 0 completely collapsed at $18 \mathrm{~s}$, as shown in Figure8. As illustrated in Figure9, the deformation of point A drastically moved along the time duration. The base shear force and internal force reached their maximum point at a period between 9 and $12 \mathrm{~s}$, which is close to the collapse time of the entire structure. The results showed that maximum internal and base shear forces occurred at the same time when the structure was about to collapse completely.

In this study, 10 models, including an original model and models with braces and shear walls, were analyzed under the El Centro (1940) and Kobe (1995) earthquake conditions. The analysis considered the effects of the earthquakes on collapse time, base shear force values, internal force values, and cross-section controls. Table 7 shows the collapse time of each model under the two earthquakes. The results indicate that, in terms of collapse time, the collapse mechanism of the models reinforced with braces provide a better outcome than that of the models reinforced by vertical shear walls.

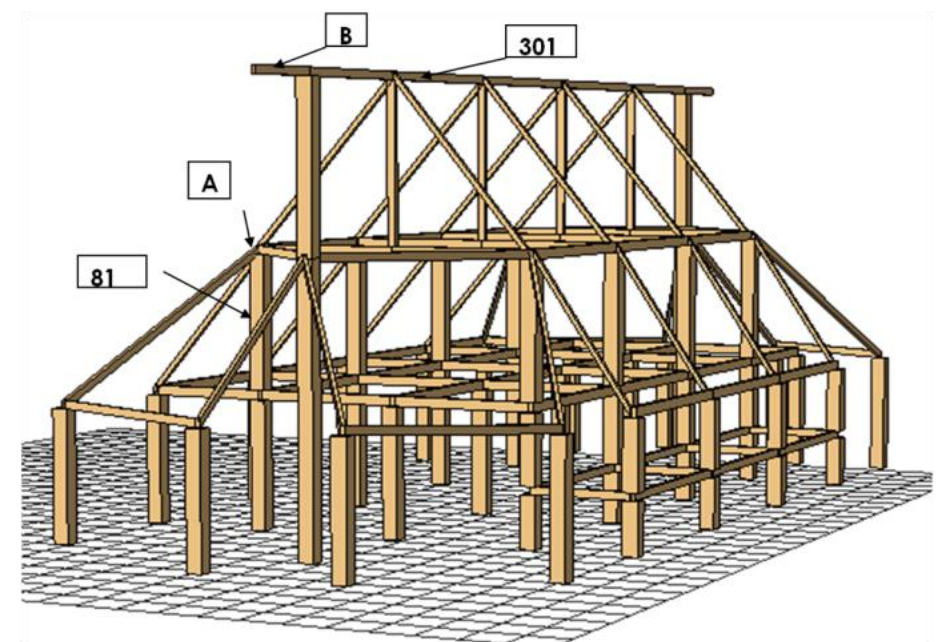

Figure 7 Beam 301, point B, column 81, and point A (x, y, z = $3.8 \mathrm{~m}, 3.48 \mathrm{~m}, 0 \mathrm{~m})$ 


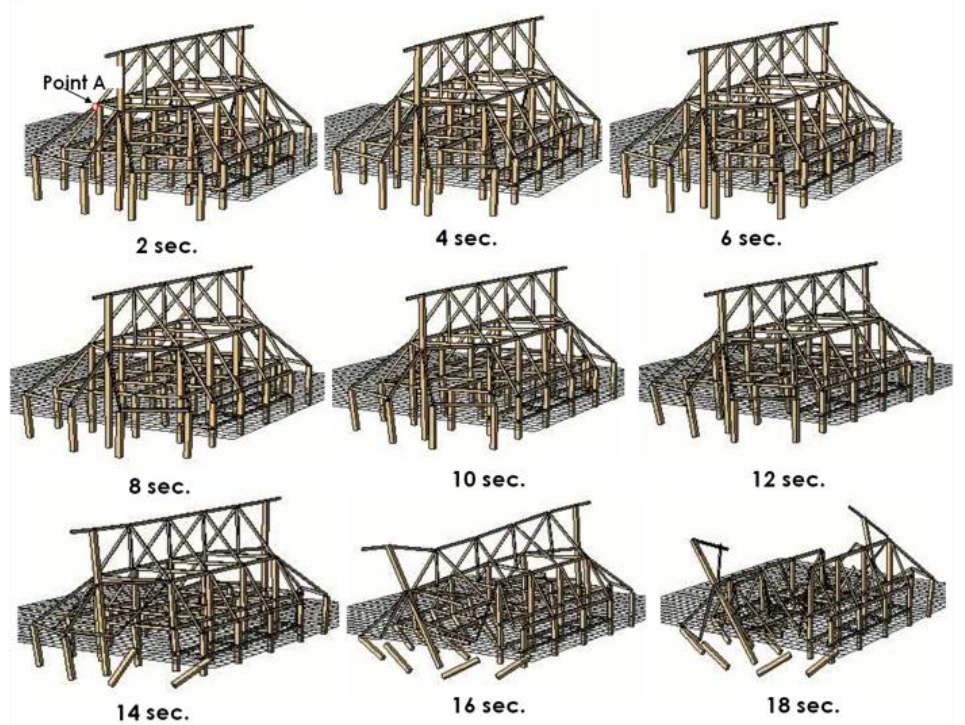

Figure 8 Collapse behavior of model 0 due to El Centro earthquake

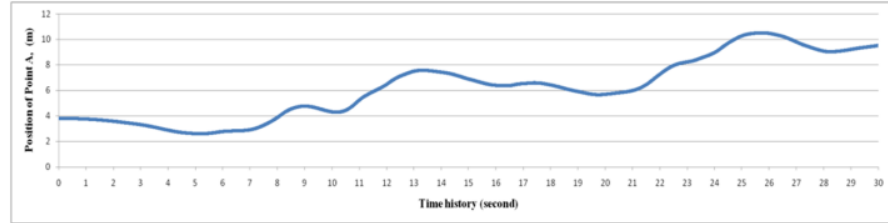

(a) Deformation of Point A

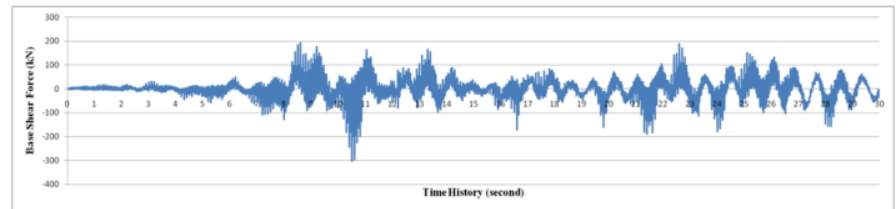

(b) Base shear in $\mathrm{x}$-direction $\left(\mathrm{V}_{\mathrm{x}}\right)(\mathrm{kN})$

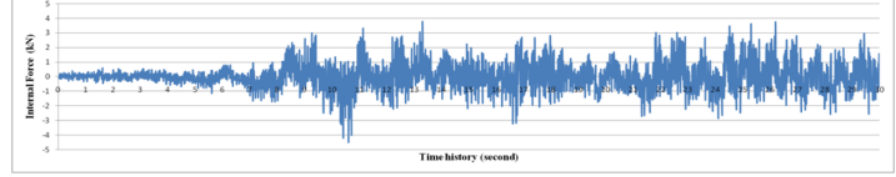

(c) Internal force in $\mathrm{x}$-direction $\left(f_{\mathrm{x}}\right)(\mathrm{kN})$

Figure 9 Wallstat program results for model 0 under El Centro earthquake

Table 7 Collapse time of each model under two earthquakes

\begin{tabular}{ccccc}
\hline Model no. & $\begin{array}{c}\text { El Centro } \\
\text { (seconds) }\end{array}$ & Status & $\begin{array}{c}\text { Kobe } \\
\text { (seconds) }\end{array}$ & Status \\
\hline 0 & 16 & Collapsed & 8 & Collapsed \\
1 & 16 & Collapsed & 8 & Collapsed \\
2 & 16 & Collapsed & 8 & Collapsed \\
3 & 16 & Collapsed & 8 & Collapsed \\
4 & 16 & Collapsed & 8 & Collapsed \\
5 & 16 & Collapsed & 8 & Collapsed \\
6 & - & Survived & - & Survived \\
7 & - & Survived & - & Survived \\
8 & - & Survived & - & Survived \\
9 & - & Survived & - & Survived \\
\hline
\end{tabular}


Models 1, 2, 3, 4, and 5 collapsed at the same time length during which model 0 collapsed. However, models 6, 7, 8, and 9, which were reinforced using braces, survived both the El Centro and Kobe earthquakes. Analysis of time-of-collapse results under strong earthquakes indicated that the bracing system at the first story was more effectivein preventing structural collapse, whereas the models with additional vertical shear walls at the second story indicated the occurrence of softness during the earthquake. Thus, we can conclude that additional braces at the first story helped to reduce the lateral movement of the entire structure, thereby enabling the house to withstand the earthquake. The main column at the first story was the main element that supported the entire structure against the earthquake. The bracing system increased the strength of connections between members at the first story, thus improving the overall structural performance during the earthquake.

Base shear force values in $x$-direction of each model are shown in Table 8 . The findings show that models 1, 3, 4, and 5 had more rigid structures and stiffer walls and columns because they had higher base shear force values than the other models, including the original. However, some of the models had smaller base shear force values probably because the configuration of the vertical shear wall was not appropriate. Thus, further research with various reinforcement configurations should be conducted to determine the best configuration for structural collapse prevention. According to the base shear-force results, the shear wall reinforcement was more effective than the bracing system in preventing structural collapse.

Table 8 Base shear values in $x$-direction of each model

\begin{tabular}{ccc}
\hline Model no. & $\begin{array}{c}\text { El Centro } \\
\text { Base Shear }\left(\mathrm{V}_{\mathrm{x}}\right), \\
\mathrm{kN}\end{array}$ & $\begin{array}{c}\text { Kobe } \\
\text { Base Shear }\left(\mathrm{V}_{\mathrm{x}}\right), \\
\mathrm{kN}\end{array}$ \\
\hline 0 & 314.249 & 260.244 \\
1 & 207.445 & 260.913 \\
2 & 157.598 & 238.972 \\
3 & 169.830 & 278.980 \\
4 & 285.461 & 359.136 \\
5 & 299.587 & 346.219 \\
6 & 300.902 & 240.727 \\
7 & 309.323 & 249.930 \\
8 & 287.768 & 238.230 \\
9 & 265.756 & 245.040 \\
\hline
\end{tabular}

Table 9 Internal forces in all models

\begin{tabular}{ccc}
\hline \multirow{2}{*}{ Model no. } & Kobe & El Centro \\
\cline { 2 - 3 } & Maximum Axial Force $(\mathrm{kN})$ & Maximum Axial Force $(\mathrm{kN})$ \\
\hline 0 & 7.947 & 4.473 \\
1 & 9.074 & 4.574 \\
2 & 10.301 & 5.891 \\
3 & 8.577 & 4.706 \\
4 & 11.476 & 5.627 \\
5 & 14.864 & 5.993 \\
6 & 10.263 & 5.350 \\
7 & 25.640 & 7.173 \\
8 & 37.310 & 9.015 \\
9 & 50.820 & 10.396 \\
\hline
\end{tabular}


Table 9 shows the internal forces that occurred in all models. The results indicate that the models reinforced with braces at the first story or with vertical shear walls at the second story have higher internal force values than the original. The results concur with the basic principle of earthquake-resistant building design that the more rigidor stiff the structure, the higher is the internal force that occurs. Generally, the internal force values show that the models with braces have higher values than those with vertical shear walls, which means that the bracing systems provide better support than the vertical shear walls.

Cross-section controls to moments and tensile force acting on column 81 and beam 301 are shown in Tables 10 and 11, respectively. The control status is based on allowable requirements in Equations1 and 2. The collapse of a structure during an earthquake is believed to be a result of many factors, including its cross-sectional resistance. Therefore, checking the cross-sectional resistance is necessary to control the feasibility of the cross-section to withstand an earthquake. The findings of the present study demonstrate that both models with bracings and vertical shear walls are acceptable and sufficient for the structure to survive the two earthquakes.

Table 10 Cross-section controls to moments and tensile force action on column 81

\begin{tabular}{|c|c|c|c|c|c|c|}
\hline \multirow[b]{2}{*}{ Model no. } & \multicolumn{3}{|c|}{ Column 81} & \multirow{2}{*}{$\begin{array}{c}\text { Tensile } \\
\text { Cross-section } \\
\text { Resistance }\end{array}$} & \multirow{2}{*}{$\begin{array}{c}\text { Compression } \\
\text { Cross-section } \\
\text { Resistance } \\
\end{array}$} & \multirow[b]{2}{*}{ Status } \\
\hline & $\mathrm{M}_{\mathrm{y}}$ (N.mm) & $\mathrm{M}_{\mathrm{z}}(\mathrm{N} . \mathrm{mm})$ & $\mathrm{T}_{\mathrm{u}}(\mathrm{N})$ & & & \\
\hline 0 & -3255000 & -12036000 & 14082 & -2.20 & -0.85 & Acceptable \\
\hline 1 & -3180000 & -9882400 & 10290 & -1.94 & -0.82 & Acceptable \\
\hline 2 & -3412000 & -11682000 & 12248 & -2.21 & -0.88 & Acceptable \\
\hline 3 & -8653000 & 13385000 & 11739 & -0.43 & -2.15 & Acceptable \\
\hline 4 & -11690000 & 11529000 & 17629 & -1.38 & -2.92 & Acceptable \\
\hline 5 & -9482000 & 13467000 & 10673 & -0.63 & -2.35 & Acceptable \\
\hline 6 & -3188000 & -8659000 & 11690 & -1.79 & -0.82 & Acceptable \\
\hline 7 & -2788000 & -9156000 & 11880 & -1.75 & -0.73 & Acceptable \\
\hline 8 & -3002000 & -8558000 & 10910 & -1.73 & -0.78 & Acceptable \\
\hline 9 & -3268000 & -8018000 & 14950 & -1.71 & -0.86 & Acceptable \\
\hline
\end{tabular}

Table 11 Cross-section controls to moments and tensile force action on beam 301

\begin{tabular}{crrrcccc}
\hline \multirow{2}{*}{ Model no. } & \multicolumn{3}{c}{ Column 81 } & \multicolumn{3}{c}{ Tensile } & Compression \\
\cline { 2 - 6 } & $\mathrm{M}_{\mathrm{y}}(\mathrm{N} . \mathrm{mm})$ & $\mathrm{M}_{\mathrm{z}}(\mathrm{N} . \mathrm{mm})$ & $\mathrm{T}_{\mathrm{u}}(\mathrm{N})$ & $\begin{array}{c}\text { Cross-section } \\
\text { Resistance }\end{array}$ & $\begin{array}{c}\text { Cross-section } \\
\text { Resistance }\end{array}$ & Status \\
\hline 0 & -5492000 & -15267000 & 16104 & -3.13 & -1.40 & Acceptable \\
1 & -10760000 & 13235000 & 10340 & -0.97 & -2.66 & Acceptable \\
2 & -10370000 & 15931000 & 15123 & -0.53 & -2.59 & Acceptable \\
3 & -8653000 & 13385000 & 11739 & -0.43 & -2.15 & Acceptable \\
4 & -11690000 & 11529000 & 17629 & -1.51 & -2.77 & Acceptable \\
5 & -9482000 & 13467000 & 10673 & -0.63 & -2.35 & Acceptable \\
6 & -6270000 & -14300000 & 19530 & -3.19 & -1.61 & Acceptable \\
7 & -5866000 & -14270000 & 18630 & -3.09 & -1.50 & Acceptable \\
8 & -7670000 & -14750000 & 18000 & -3.59 & -1.94 & Acceptable \\
9 & -7686000 & -13340000 & 30650 & -3.38 & -2.0 & Acceptable \\
\hline
\end{tabular}

\section{CONCLUSION}

In this study, 10 structural models numbered from 0 to 9 were generated in the Wallstat program. Model 0 showed the original structure without any reinforcement. Models 1 to 5 were equipped with vertical shear walls, and models 6 to 9 had diagonal bracings. Each reinforced 
model had a different bracing or shear wall configuration. These models were observed under the conditions of the El Centro (1940) and Kobe (1995) earthquakes. The results were then analyzed considering the earthquake effects on collapse time, base shear-force values, internal force values, and cross-section controls. The results indicated that generally, the models with bracing reinforcement exhibited better results than those with vertical shear walls. Thus, these research findings can be used as a reference to provide ideas in strengthening traditional heritage houses so that they can withstand future earthquakes.

\section{ACKNOWLEDGEMENT}

The authors would like to thank I Ketut Suwantara research team PTPT of Denpasar for supporting this research project by providing required data and partial experimental results on the Ammu Hawu house in NTT province.

\section{REFERENCE}

Anonymous, 1983. Peraturan Pembebanan Indonesia untuk Gedung (PPIUG)

Awaludin, A., Pribadi A., 2012.Lateral Resistance of Sengon Wooden Panel with Nail Cutting Tools due to Monotonic and Cyclic Loads (Tahanan Lateral Panel Kayu Sengon dengan Alat Sambung Paku Akibat Beban Monotonik dan Siklik). Thesis report, Civil and Environmental Engineering Department, Gadjah Mada University

Awaludin, A., 2010. A Review on Indonesian Traditional Timber House Sustainability. In: Proceeding of the International Conference on Sustainable Built Environment, Yogyakarta

Awaludin, A. 2012.Development of Structural Walls made from LVL Sengon (Paraserianthes falcataria): Basic Mechanical Properties.In: Sustainable Civil Engineering Structures and Construction Material (SCESCM) Conference, Gadjah Mada University, Yogyakarta

Building Research Institute, 2010. Wallstat Manual E-book

Idham N.C.,2010.Why the Javanese Houses Have Failed in the 2006 Earthquake. In: Proceeding of the International Conference on Sustainable Built Environment (ICSBE), Volume 1, pp. 121-128

Kinasih, I.P., Wiriasto, G.W.,Kanata, B., Zubaidah, T., 2014.Lesser Sunda Islands Earthquake Inter-occurence Times Distribution Modeling, International Journal of Technology, Volume5(3), pp. 242-250

Nakagawa, T, Ohta M.,2003.Collapsing Process Simulations of Timber Structures under Dynamic Loading I: Numerical Simulations of the Real Size Wooden Houses.Journal of Wood Science, Volume 49(5), pp. 392-397

Nakagawa, T., Ohta M.,2003. Collapsing Process Simulations of Timber Structures under Dynamic Loading II: Simplification and Quantification of the Calculating Method.Journal of Wood Science, Volume 49(6), pp.499-504

Nakagawa, T., Ohta M.,Tsuchimoto, T., Kawai, N., 2010.Collapsing Process Simulations of Timber Structures under Dynamic Loading III: Numerical Simulations of the Real-size Wooden Houses.Journal of Wood Science, Volume 56(4), pp.284-292

Suwantara I.K., Rusli., 2013. Experimental Research on Friction Shear of Kayk Lontar Column Connection with Stone at Ammu Hawu House, NTT province (Penelitian Eksperimen Geser Friksi Sambungan tiang Kayk Lontar dengan Batu pada Rumah Ammu Hawu, Provinsi NTT.Jurnal Teoritis dan Terapan Bidang Rekayasa Sipil, Volume 20(2), pp. 7986

Standar Nasional Indonesia (SNI), 2000. 03-xxxx-2000: Procedures for Wood Structure Planning for Building Buildings(Tata Cara Perencanaan Struktur Kayu Untuk Bangunan Gedung) Beta Version, Bandung 
Triyadi S., Harapan A., 2009. Lesson Learn from Traditional Sustainable Construction.In: Proceedings of the International Conference on Sustainable Infrastructure and Built Environment, Bandung, West Java, November 2-3

USGS Earthquake Hazards, 2009.Availbale online at http://earthquake.usgs.gov/ 